\title{
Preservation of Ketuwinan Tradition to Establish Relationships between Communities in Kendal, Indonesia
}

\author{
Fitri Ariana Putri \\ Universitas Islam Negeri Walisongo Semarang, Indonesia \\ email: fitriarianaputri@gmail.com
}

\begin{abstract}
The Ketuwinan tradition is a form of spread of Islam in Kaliwungu, Kendal in the 16 th century $A D$. One of the spread of Islam through walisongo is a culture that culturing between culture and religion which is packaged attractively to captivate the hearts of the people to Islam, but is does without abandoning the previous teachings (tradition). This tradition has three wasilah, namely mahabbah, maghfiroh, and syafa'ah. To create a sense of love for the Prophet Muhammad SAW, the people of Kaliwungu, Kendal carried out the Ketuwinan tradition which is still carried on today. This tradition is commemorated on the 12th of Rabiul Awwal to coincide with the birth of Prophet Muhammad saw. The acculturation of this tradition with religion has positive goals in society, so it needs to be preserved. The positive value between communities is to strengthen the friendship. The purpose of this study was to explore the Ketuwinan to establish friendship between communities in Kaliwungu, Kendal. In this study is using qualitative research with a phenomenological approach. And the results of these findings the community continues to preserve existing traditions and teach children about goodness with positive values, namely sharing, giving, giving alms and meeting with relatives to strengthen ties.
\end{abstract}

Keywords: Ketuwinan Tradition, Gathering, Kaliwungu, Kendal

\section{ABSTRAK}

Tradisi Ketuwinan adalah sebuah bentuk penyebaran Islam di Kaliwungu, Kendal pada abad ke $16 \mathrm{M}$. Penyebaran Islam yang dilakukan oleh walisongo ini yakni dengan mengakulturasikan antara budaya dengan agama yang dikemas secara menarik untuk memikat hati masyarakat dalam beragama Islam, namun tidak meninggalkan ajaran sebelumnya (tradisi). Tradisi ini mempunyai tiga wasilah yaitu mahabbah maghfiroh dan syafa'ah. Untuk mewujudkan rasa cinta kepada Nabi Muhammad SAW, maka masyarakat Kaliwungu, Kendal melaksanakan tradisi Ketuwinan yang masih diletarikan hingga saat ini. Tradisi ini diperingati pada tanggal 12 Rabiul Awwal bertepatan dengan lahirnya Nabi Muhammad saw. Akulturasi tradisi dengan agama ini mempunyai tujuan yang positif di masyarakat, sehingga perlu dilestarikan. Nilai positif yang berkembang 
di masyarakat dari hal tersebut yakni mempererat tali silaturahim. Tujuan dari penelitian ini yaitu untuk mengetahui tradisi Ketuwinan untuk menjalin silaturahim antarmasyarakat di Kaliwungu, Kendal. Penelitian ini menggunakan penelitian kualitatif dengan pendekatan fenomenologi. Temuan studi ini menunjukkan bahwa masyarakat terus melestarikan tradisi yang telah ada dan mengajarkan anak-anak mereka tentang kebaikan serta nilai-nilai positif seperti saling berbagi, memberi, bersedekah, dan bertemu sanak saudara untuk mempererat tali silaturahim.

Kata Kunci: Tradisi Ketuwinan, Silaturahim, Kaliwungu, Kendal

\section{INTRODUCTION}

Indonesia is a compound nation that has a variety of cultures. Indonesia has a strategic location and fertile land with abundant natural wealth. According to Anthony Reid, Indonesian is a country under the wind because of the importance of Indonesia's position in the eyes of the world. This strategic situation is what causes all foreign cultural flows to enter Indonesia. The incoming culture can cause the cultures in Indonesia to get richer and can influence the development of local culture that existed for generations, so that the culture in Indonesia is diverse and unique (Sutardi, 2007: 9).

People and culture are two things that cannot be separated, because they affect each other. Human is always in touch with the culture of the creations, feelings, the attitude of the person who is influenced from the place where he lives. Then there will appear a culture that is built in the environment by forming a person's attitude and mindset. People must be able to adapt to culture and tradition in accordance with the residential environment. Due to the cultural diversity in Indonesia, as a human being, people are required to know and understand the culture and traditions that have been preserved in the area.

In general, culture is formed from seven elements of universal culture. The seven cultural elements are: language, knowledge system, social organization, living equipment system and technology, livelihood system, religious system, and arts. The element that forms a culture is tradition. One of the traditions in Kaliwungu, Kendal, is also one of the characteristics that distinguishes it from other regions. The existence of a difference indicates the inequality that culture needs to be studied to know the culture in each region (Sari, 2019, Vol 8, No 1: 42)

The culture in Kaliwungu, Kendal is now a tradition that is usually carried out once a year on the anniversary of the Prophet Muhammad's Birthday called Ketuwinan. This tradition still runs until now in Kaliwungu, Kendal which is carried out by all 9 villages in Kaliwungu, Kendal (https://keckaliwungu.kendalkab.go.id/desa_kelurahan, accessed on Sunday, November 21, 2020, at $06.21 \mathrm{WIB}$ ). The community continues to preserve this tradition with the aim of strengthening the brotherhood between the community as well as family relatives. With this tradition, it can foster positive values in society such as giving, showing affection, loving each other to foster a high sense of social care for others (Sari, 2019, Vol 8, No 1: 43).

Social care that is built in this community can be seen from the enthusiastic attitude when carrying out this Ketuwinan, so that it can reflect the community's delight when carrying out the 
traditions of the ancestors. The emergence of Ketuwinan tradition since the beginning of Islam entered Kaliwungu makes it one of the ways when the spread of Islam in Kaliwungu, Kendal. The condition of the community with a high sense of concern has excellent benefits for the future. Starting from young children who are taught to have an attitude of giving each other and visiting each other's houses between neighbours. This is to connect the ropes of youth while preserving the local culture by providing an understanding of the importance of gathering must be maintained (Sari, 2019, Vol 8, No 1: 43).

So far, the study of the tradition of mating conducted by researchers focuses on the implications of ukhuwah Islamiyah of the value contained in the tradition of mating while the study of gathering as a form of preservation of marriage to establish a sense of kinship between communities focuses on three wasilah namely a) Mahabbah, b) Maghfiroh and c) Syafa'ah. Research on the tradition of marriage in Kaliwungu, Kendal has been done a lot. Firstly, Ethnomatematic Study of Weh-Wehan Tradition in Kaliwungu Subdistrict, Kendal conducted by Aini Fitriyah (Fitriyah, 2021, Vol 6, No 1: 50).

This study examined ethnomathematics in the weh-wehan tradition in Kaliwungu Kendal Subdistrict with qualitative approach. The results of this study contain five of the six existing mathematical fundamental activities namely counting, locating, designing, playing and explaining. Secondly, The Tradition of The Celebration of Kenduri Maulid Nabi in Aceh Besar conducted by Muhammad Yunus (Yunus, 2020, Vol 22, No 2: 33). The discussion in this study is about the celebration of the Prophet's birthday with kenduri tradition held in three months, starting from the month of Rabiul Awal, Rabiul Akhir, and Jumadil Awal. Then, one day from three months is selected as a form of celebration of maulid kenduri. The celebration of the day of the maulid is a form of realizing and glorifying the day of the Prophet's birth. Kenduri Maulid in each sub-district in Aceh Besar varies as it lies in the dish as well as the time and place in the celebration.

The study of the tradition of marriage and celebration of the Prophet's birthday has been there before. Additionally, this is the research on gathering as a form of preservation of tradition. The Third is the research on Kupatan, the tradition of preserving the Teachings of Charity, Strengthening the Cords of Friendship and Glorifying Guests by Wildan Rijal Amin (Amen, 2017, Vol 14, No 2: 268).

This study describes the tradition of Kupatan which is commemorated on the eighth day of syawal or to commemorate after fasting syawal for six days. Durenan village celebrates the tradition of Kupatan with diving practiced by Javanese people with open house by preparing dishes for the guests with the aim of getting Kupatan blessings. Unfortunately, people do not know the meaning of the tradition, but they believe that Kupatan tradition is a legacy of its ancestors. So, this tradition is still preserved. The fourth is a research that discusses the challenges of tradition in Kendal, one of which is titled Tedhak Siten Tradition Meaning research on Kendal Society: A Phenomenological Analysis of Alfred Schutz by Tika Ristia Djaya (Djaya, 2020, Vol 1, No 6: 21). This study aims to know the public perception in interpreting the tradition of tedhak siten in Kendal society which is analysed using phenomenological. The results of this study through alfred schutz phenomenological analysis that became a symptom and social reality and made the object of formal study, that the tradition of tedhak siten is a legacy of ancestors that is still preserved to this day. 
Some studies that have been done show that there has been no focus of studies on the tradition of mating as a form of preservation of gathering with three wasilah namely a) Mahabbah, b) Maghfiroh and c) Syafa'ah. This study is to complement previous research and this study helps provide data for researchers who will come in later in life.

Thus, in line with the research, three questions can be formulated: a) Background of the emergence of ketuwinan tradition? b) How is the procession of the implementation of ketuwinan tradition in Kaliwungu, Kendal? c) What is the concept of inter-community gathering in ketuwinan tradition in Kaliwungu, Kendal?

\section{METHODS}

This research uses qualitative research method with phenomenological approach. Qualitative research is research or study that is descriptive and tends to use analysis with inductive approach. Qualitative research emphasizes reasoning, meaning, definition of a particular situation (in a particular context). As well as those related to things in everyday life more are researching (Rukin, 2019: 6). Meanwhile, the approach used in this study is phenomenology.

According to Moleong, this phenomenological approach has the meaning of events and their relation to ordinary people in certain situations. Phenomenological studies do not assume that these researchers to know the meaning of something for the people being studied. These phenomenologists emphasize the subjective aspects of cultural behaviour (Endraswara, 2006: 7), so there needs to be involvement of the perpetrator to interpret an event. Phenomenology also seeks to express, understand, and learn a distinctive and unique phenomenon experienced by an individual to reach the level of belief of the individual concerned or based on the point of view of the person experiencing the event directly (Herdiansyah, 2012: 59).

The method of data collection in this study which uses in-depth interview techniques will be used as primary data. Primary data is obtained from field studies through interviews directly or online (via WhatsApp) with informants related to the problem to be researched. The subject is the people in Kaliwungu, Kendal, the ancestors or who understand historically related to the tradition of Ketuwinan and the youth who live the tradition of Ketuwinan every year while the secondary data is by means of documentation such as decryption of interview results, journals, books, videos and so on.

\section{RESULTS AND DISCUSSION}

\subsection{Background of The Emergence Ketuwinan Tradition}

According to Dr. Mudjahirin Thohir, MA, the emergence of this Ketuwinan tradition is the beginning of Islam entering Kaliwungu, Kendal in the 16th century AD. Islam teaches law and morality. Ketuwinan is part of mauluddan to commemorate the death of the Prophet Muhammad SAW. Then, this tradition has three wasilah namely a) Mahabbah, b) Maghfiroh and c) Intercession. To realize the love for the Prophet Muhammad SAW, the people of Kaliwungu, Kendal carry out this wedding tradition began with the reading of maulud to get intercession and maghfiroh (Interview Dr. Mudjahirin Thohir, MA, as a historical figure in Kaliwungu, Kendal, on Tuesday, November 24, 2020, at 19.15 WIB). 
According to the Great Dictionary of The Indonesian Language, tradition is a traditional custom for generations (from ancestors) that is still carried out in the community, with the assessment or assumption that the best and correct ways (Muzzakir, 2018: 77). The understanding of the tradition in the language comes from the Latin tradition, which means continued or habitual. Meanwhile, traditionally it contains a hidden understanding of the existence of a connection of the past with the present (Fajrie, 2016: 23).

In general, tradition is part of the cultural system of society. Tradition can be said to be a cultural inheritance from ancestors, who have lived for hundreds of years and continue to run from generation to generation. Tradition is also considered very good by those who have it, even considered irrefutable or abandoned by them. From the tradition that has existed since long ago, it turns out to have religious values, especially in Far Eastern countries, such as China, Thailand, Japan, the Philippines and especially in Indonesia (Simanjutak, 2016: 145).

The existence of a regional tradition must have continuity in culture. According to Edward B. Taylor, he saw culture as a complex matter that included knowledge, belief, art, morals, law, customs, abilities, habits, or all things that man had as a member of society (Maryati, 2007: 109). Therefore, nowadays it must be able to maintain the tradition that existed since ancient times.

The culture here looks unique and owned by various regions, that can add colour and pattern in life. Culture has also become a characteristic in each region with moral values and traditional values that must be maintained. In culture, it also captures reality, which means not only pursuing factual things, but also related to abstract cultural phenomena (Endraswara, 2006: 79-80). Generally, culture can be distinguished into two, namely: a) intangible (non-physical) meaning that a thing cannot be held or intangible. It can also be classified into abstract that is in the human mind. For example, tradition, belief, art, behaviour, mindset and others, b) tangible (physical) means concrete objects that can be held or tangible in the form of actions, such as forts, mosques, churches, traditional houses and others (Deputy Team for Preservation and Cultural Development, 2004: 4).

Cultures preserved in Kaliwungu, Kendal has now become an annual tradition that is often referred to as the Ketuwinan tradition. Ketuwinan tradition comes from two words namely tradition and Ketuwinan. Both have their own understandings. Tradition is interpreted as a customary custom inherited from ancestors, while the sense of Ketuwinan comes from the Javanese language tuwi (tilik)- nuweni (niliki, visiting)- then Ketuwinan means to visit each other. Therefore, ketuwinan tradition is to visit each other between neighbours, relatives, relatives by exchanging food that aims to strengthen the relationship. Ketuwinan tradition is also often referred to weh-wehan tradition by kaliwungu people. This is because in the implementation of the tradition between people Kaliwungu give each other or in Javanese language that is aweh means to give, so it is better known by the community with the tradition of weh-wehan (Malikhah, 2019: 39-40).

Ketuwinan has been a tradition that is hereditary and still maintained today. The tradition of Marriage becomes an important part that contains moral values, family values as a way to strengthen the relationship by giving each other. If this tradition has been lost in the community, then the momentum to gather gives each other the same as the usual days. This tradition is highly anticipated by the community every year because the community also feels the need and makes it an obligation of everyone (Wahidi, 2015, Vol 5, No 2: 203). People celebrate this tradition as it is Eid 
al-Fitr. When Eid al-Fitr, children get a gift in the form of money (angpao), however, in tradition of marriage, they get the form of special snacks.

Ketuwinan or weh-wehan is a hereditary tradition carried out by the people of Kaliwungu, Kendal. This tradition has existed since the beginning of the spread of Islam in Kaliwungu and its surroundings (Interview with Apriliya, as a community in Kaliwungu, Kendal, on Sunday, November 15,2020 , at 17.58 WIB). Ketuwinan is a ceremony or celebration performed by kaliwungu people as a form of gratitude to God for the birth of Rosulullah (Malikhah, 2019: 82). The form of Ketuwinan in Kaliwungu is the food served varies according to their variety, but the dish that is not left behind in this tradition is the presence of traditional food. Unfortunately, as the era of this tradition has evolved, people do not know the original history. People just carry out the tradition with joy because it is only celebrated once a year.

The existence of traditional food in Ketuwinan in Kaliwungu has become an inherent part of this tradition because it has existed since the previous generation. Traditional foods include sumpil, sticky rice, ambegan, apem and market food. Among the traditional foods, sumpil is the most typical food in Kaliwungu, its existence is always never left to be served in the event Ketuwinan (Sofi, 2018: 4). As the times have evolved, the food served also adapts to the current situation. Sumpil is the main characteristic, but not all people make or give sumpil to others only a few. Now, people prefer food that is practical and modern as well as varied (Interview Dr. Mudjahirin Thohir, MA, as a culturalist in Kaliwungu, Kendal, on Tuesday, November 24, 2020, at 19.15 WIB).

\subsection{Procession of Ketuwinan Tradition in Kaliwungu, Kendal}

Muslims commemorate the death of the Prophet Muhammad SAW, usually with dzibaan or mauluddan. Similarly, in Kaliwungu, starting from the early rabbiul month on the 1st until the peak of the 12th of the early rabbiul. Then the peak in the afternoon followed by the implementation of this ketuwinan tradition (Interview Dr. Mudjahirin Thohir, MA, as a culturalist in Kaliwungu, Kendal, on Tuesday, November 24, 2020, at 19.15 WIB). The implementation of this Ketuwinan tradition was carried out a long time ago. Ketuwinan tradition is carried out in commemoration of the great day of Islam, namely Maulud Prophet Muhammad SAW.

The procession at the time of ketuwinan tradition is divided into two: the first stage of preparation, generally carried out when the tradition is carried out. The preparation is to prepare the things needed to carry out the ketuwinan, ranging from preparing decorative lamp trinkets, preparing dishes that will be given to others, preparing the place of laying dishes to be served and the preparation of the perpetrator who delivers the food to the neighbours (Malikhah, 2019: 1314). The second is implementation, where the children visit their neighbours and then handing out food that they had then exchanged for the food of the neighbours they visited. This tradition can serve as a knowledge to share with others from an early age that will be aimed at every child who attends the event. So, one day children grow up, they will be generous and willing to share to each other (Interview with Nisrina Nur, as a student figure in Kaliwungu, Kendal, on Thursday, November 19, 2020, at 21.04 WIB).

The Spirit and happiness of people of Kaliwungu toward the tradition of Ketuwinan is strongly felt when being close to the center of religious development, namely al-Muttaqin Kaliwungu mosque, but if it gets further away from the center then the nuances are different. Based on these 
things, some scholars and Kyai in Kaliwungu took the initiative to make an activity that is able to foster the spirit of the community in carrying out the tradition of Ketuwinan and also give guidance to the people of Kaliwungu to better understand of the values contained in the tradition, especially for people who are immigrants, so that this tradition is maintained and preserved so as not to be lost eaten by the times (Malikhahhah , 2019: 13-14).

Figure 1. Procession during the implementation of Ketuwinan

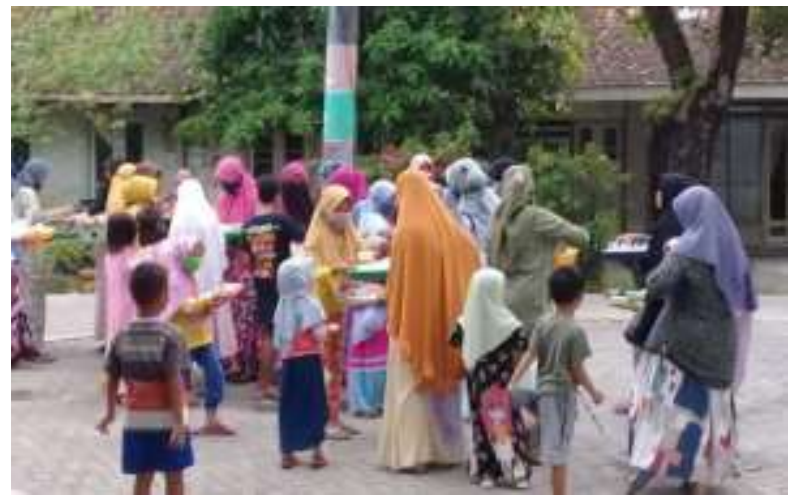

From children up to parents in Kaliwungu celebrate this tradition with pleasure. The tradition that is only once a year, makes the community happy, especially for children who collect traditional snacks as a variety of creativity of citizens to be able to develop. It is an annual tradition that is always celebrated. The tradition of exchanging snacks and food has become a routine activity of kaliwungu's people as a form of gratitude to welcome the birth of Maulud Nabi Muhammad SAW (Arif, 2020)

The implementation of ketuwinan is certainly inseparable from the touch of Islam brought by the students, because Kaliwungu is known as the city of santri where there are many Islamic boarding school and it is the center of religious learning. Ketuwinan tradition is also a form of da'wah that uses tradition as a forum in spreading Islamic values in the community. The people in Kaliwungu, Kendal develop, maintain, and improve the implementation of ketuwinan every year in order to spread goodness and internalize religious values (Malikhah, 2019: 16).

Along with the times, ranging from given food that was formerly with traditional food, now combined with modern foods. However, it does not eliminate the essence of value in Ketuwinan.

Figure 2. Food in the Tradition of Ketuwinan

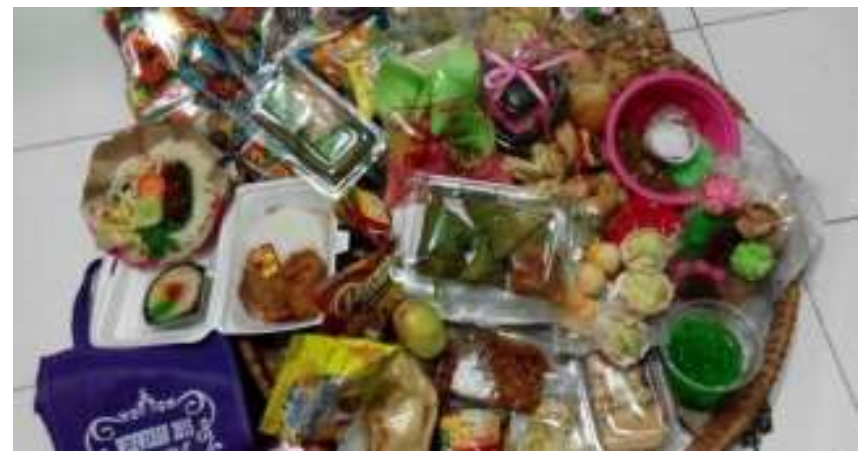

Starting in feeding or giving food to others is a form of concern and charity. Thus, having a philosophy when visiting other people's homes should bring food. The philosophical meaning of this is that it would be better to bring food when visiting other houses. In Eid, the tradition of Ketuwinan 
is also called bodo maulud (lebaran maulud). With the development of social media, now greetings commemorating each other's birthday of the prophet Muhaammad SAW is not only done directly or face-to-face. Today's youth take pride in their own traditions. For example, in Kaliwungu, Kendal, there are a lot of speeches made virtually such as status, video or photos uploaded on social media or during the implementation procession.

Figure 3. Speech uploads on social media

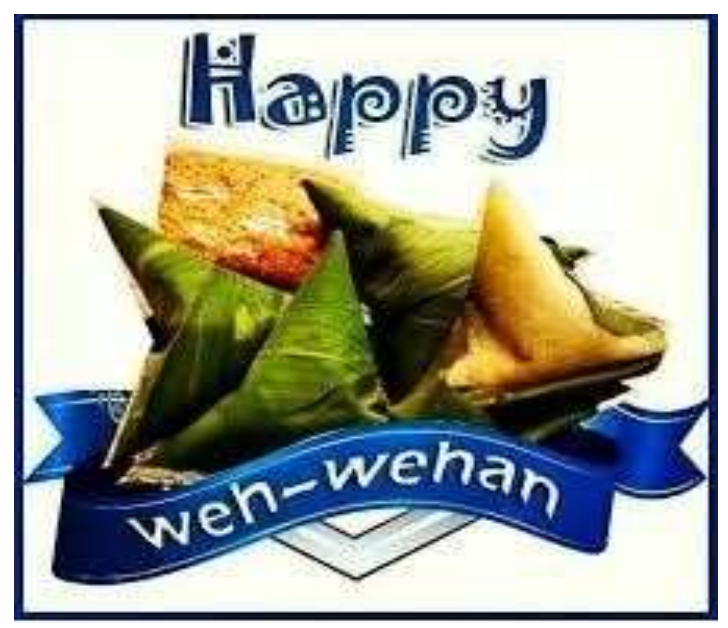

\subsection{Concept of gathering among the community in The Tradition of Ketuwinan in Kaliwungu}

In the concept of inter-community gathering in Kaliwungu, Kendal on this Ketuwinan tradition, the community upholds religious values in commemorating the birth of the Prophet Muhammad SAW. Collaboration of tradition with this religion has a positive purpose in the community, so it needs to be preserved. The positive value between communities is by strengthening the relationship. gathering is an effective way of cultivating the soul, the credibility in the gathering of activities everyone meets in happiness. With gathering, people can exchange information and opportunities. Thus, it will make the door of sustenance opened or extend its life. As narrated by Abu Hurayrah R. A. The Prophet (pbuh) said (Saleh, 2020: 83).

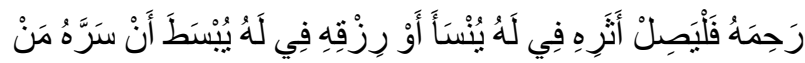

It means: "Whoever likes his sustenance expanded and his age lengthened, let him connect his relatives (gathering)." (Narrated by Al-Bukhaari and Muslim).

Being gathered means that the love affair of brotherly will be stronger in the form of loyalty, care and attention fostered by establishing gathering. The meaning of the hadith above is if it will prolong its life then by giving meaning to benefit others and passed by gathering to others by reminding each other in terms of kindness, giving direction, exchanging information. Gathering which can now be done virtually is still upheld this Ketuwinan tradition in Kaliwungu, Kendal, because the community is enthusiastic and the long-awaited moment especially for children. It is such a great happiness when wearing the best clothes to meet the community and get a lot of food. The annual tradition that is still preserved by the community is now keeping up with the times. It started with a traditional food which is sumpil, the community has replaced with modern food and more practical. 
When commemorating the Ketuwinan tradition, the community also decorates the hometown with great fanfare to preserve the existing tradition. The community decorates the village with a variety of snacks that will be distributed after carrying out the commemoration of the Prophet Muhammad's Birthday. This year becomes a different thing from the previous year, because the community commemorates the tradition by keeping a distance and wearing a mask in accordance with health protocols. In the website of TRIBUNJATENG.COM, KENDAL- Weh-wehan is an expression of gratitude to welcome the birth of the Great Prophet Muhammad SAW who brings Islamic teachings and will give intercession in the future yaumul kiyamah," said Fatmawati as a citizen. As the next generation of Kaliwungu citizens, he will continue to preserve this tradition because it teaches the value of togetherness and mutual sharing, as well as maintaining harmony between citizens. Fatmawati also said that during the Covid-19 virus pandemic, residents continue to comply with health protocols by using masks when sharing food (Imanulhaq, in the https://jateng.tribunnews.com/2020/10/29/warga-kaliwungu-kendal-gelar-tradisi-weh-wehan-2020 page, accessed on Thursday, November 26, 2020, at 10:15 a.m.

The condition of Kaliwungu people is considered to have a high sense of social care, and the existence of this Ketuwinan tradition is not the condition of the community lacks gathering. However, it is to strengthen and uphold the existing traditions (Interview Dr. Mudjahirin Thohir, MA, as a historical figure in Kaliwungu, Kendal, on Tuesday, November 24, 2020, at 19.15 WIB). Thus, it is interpreted after Islam entered in Kaliwungu then for its spread with the tradition of Ketuwinan which is commemorated every 12th of Rabiul Awwal. As his philosophy, people conduct Ketuwinan to express joy with the coming of the Prophet. Therefore, Muslims welcome with dzibaan or mauluddan (blessings of the Prophet). Ketuwinan tradition exists after Islam entered the area of Kaliwungu, Kendal, then as one to spread Islam by acculturating cultures. The tradition of Ketuwinan, up to now, is not known exactly when it was created, because the tradition is a hereditary thing from the ancestors. It is not like the birth or establishment of an area, waiting until there is a decree that applies and the exact decree. Ketuwinan becomes a symbol of gratitude and upholds the birth of the Prophet Muhammad SAW.

Bershalawat as a form of application of loving the Apostle, that is the wasilah of Ketuwinan. Above, it has been explained if there are three wasilah namely mahabbah, maghfiroh and intercession. All three have a correlation starting with mahabbah as it is obligatory to love the Prophet, to obtain maghfiroh (forgiveness) and intercession of the Prophet Muhammad SAW later in the last day. As in the hadith, there is in the story of 'Umar ibn al-Khaththab Radhiyallahu anhu, namely a hadith from Companions 'Abdullah bin Hisham R. A, said:

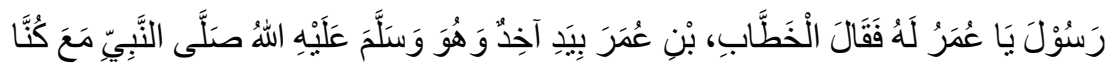

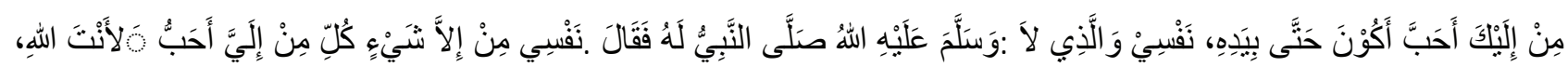

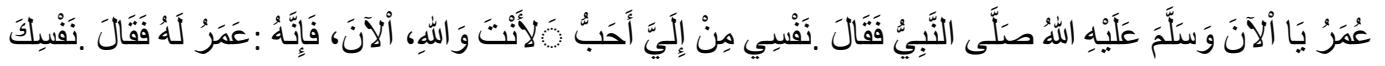

It means: "We accompanied the Prophet (peace and blessings of Allah be upon him), and he took the hand of 'Umar ibn al-Khaththab Radhiyallahu anhu. Then 'Umar said to the Prophet (peace and blessings of Allaah be upon him): 'O Messenger of Allah, I love you more than anything but myself.' The Prophet (peace and blessings of Allaah be upon him) replied: 'No, by the sake of which my soul is in His hands, that I love you more than you.' 'Umar said to him, 'Surely now is the time, by Allah, I 
love you more than I do.' The Prophet (peace and blessings of Allah be upon him) said: 'Now (you are right), O 'Umar.

From the hadith above, it is obligatory to love the Prophet and take precedence over others, except love to Allah SAW. Loving the Messenger of God is love because of God. It increases with increasing love for Allah in the heart of a Muslim and decreases with reduced love for Allah (AlUstadz Yazid bin Abdul Qadir Jawas, in the https://almanhaj.or.id/3220-wajibnya-mencintai-danmengagungkan-nabi-muhammad-wajibnya-mentaati-dan-meneladani-nabi.html website, accessed on Wednesday, November 26, 2020, at 10:59 a.m.).

Gathering that occurs at the time of the tradition of Ketuwinan, is a very visible attitude when this tradition takes place, because this tradition of marriage is an activity of visiting each other, mutual respect, and giving each other from other houses to bring a pleasant mood for the community who follow this tradition of marriage and gathering as a form of peace between communities (Sari, 2019: 50).

In Kaliwungu, Kendal, the major religion is Islam, so that with Ketuwinan that still exists from generation to generation is not a problem. Thus, it becomes an example for other regions in the need to maintain cultural preservation. Seen today, the area around Kaliwungu, apparently also follows this Ketuwinan tradition. Considered the many values contained, it would be nice to imitate. However, the essence feels different because other regions just follow it. It is different from Kaliwungu which is indeed a tradition that has existed since ancient times. Thus, the importance of preserving traditions have existed since ancient times. It is such an unfortunate if the community, until now, have not understand the origin of this Ketuwinan tradition appeared in Kaliwungu, Kendal. People only participate and invite relatives in carrying out this tradition. So there needs to be a study of culture or tradition in Kaliwungu, Kendal in order to understand how the tradition exists. Similarly, other areas, close to Kaliwungu, Kendal, participated in carrying out this tradition, just "follow-up" because they saw a good and high positive value in the community.

Figure 4: Documentation

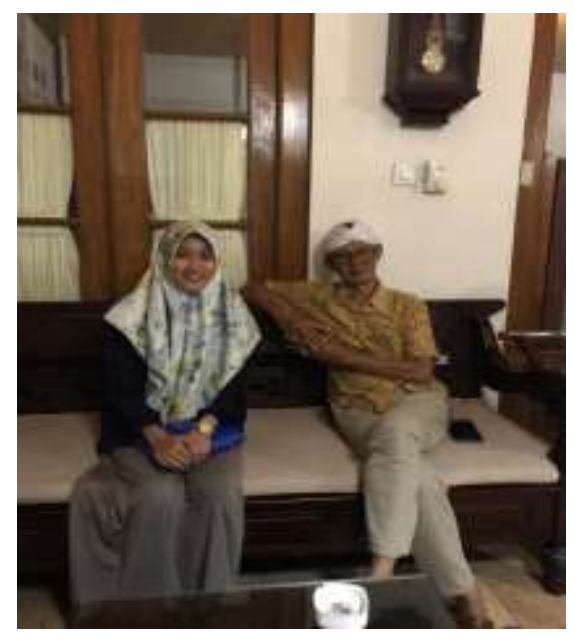

Interview of Dr. Mudjahirin Thohir, MA, as a historical figure in Kaliwungu, Kendal on Tuesday, November 24,2020 , at 19.15 WIB 


\section{CONCLUSION}

Ketuwinan tradition is a form of spreading Islam in Kaliwungu, Kendal in the 16th century AD. This tradition has three wasilah namely a) Mahabbah, b) Maghfiroh and c) Intercession. To realize the love for the Prophet Muhammad SAW, the people of Kaliwungu, Kendal carry out ketuwinan began with the reading of maulud to get intercession and maghfiroh. Then, the traditional food that exists, sumpil is the most typical food in Kaliwungu, its existence is always never left to be served in the event Ketuwinan.

Muslims commemorate the death of the Prophet Muhammad SAW, usually with dzibaan or mauluddan. Similarly, in Kaliwungu, starting the early rabbiul month on the 1st to the peak of the 12th. Then the peak in the afternoon continued with the implementation of this Ketuwinan tradition. The procession at the time of Ketuwinan tradition is divided into two: the preparatory stage and the implementation stage. Unfortunately, along with the times, ranging from given food that was formerly with traditional food, it now combined with modern foods. However, it does not eliminate the essence of value in Ketuwinan.

The collaboration of tradition and religion has a positive purpose in society, so it needs to be preserved. The positive value between communities is by strengthening the relationship as a form of peace between communities.

\section{REFERENCES}

Abduh Imanulhaq, dalam laman https://jateng.tribunnews.com/2020/10/29/warga- kaliwungukendal-gelar-tradisi-weh-wehan-2020, diakses pada hari Kamis, 26 November 2020, pukul 10.15 WIB.

Al-Ustadz Yazid bin Abdul Qadir Jawas, dalam laman https://almanhaj.or.id/3220- wajibnyamencintai-dan-mengagungkan-nabi-muhammad-wajibnya- mentaati-dan-meneladaninabi.html, diakses pada hari Rabu, 26 November 2020, pukul 10.59 WIB.

Amin, W. R. (2017). Kupatan, Tradisi Untuk Melestarikan Ajaran Bersedekah, Memperkuat Tali Silaturahmi, Dan Memuliakan Tamu. Al-A'raf: Jurnal Pemikiran Islam Dan Filsafat, 14(2). https://doi.org/10.22515/ajpif.v14i2.893.

Arif, Abdul. (2020). "Menengok Kerukunan dalam Tradisi Weh-Wehan", pada 29 Oktober 2020,dalam laman https://www.ayosemarang.com/read/2020/10/29/66173/menengokkerukunan-dalam-tradisi-weh-wehan, diakses pada hari Selasa, 24 November 2020, pukul 10.39 WIB.

Djaya, T. R. (2020). Makna Tradisi Tedhak Siten Pada Masyarakat Kendal: Sebuah Analisis Fenomenologis Alfred Schutz. Jurnal Ekonomi, Sosial \& Humaniora, 1(06).

Endraswara, Suwardi. (2006). Metode, Teknik Penelitian Kebudayaan. Yogyakarta: Pustaka Widyatama.

Fajrie, Mahfudlah. (2016). Budaya Masyarakat Pesisir Wedung Jawa Tengah: Melihat Gaya Komunikasi dan Tradisi Pesisiran. Wonosobo: Mangku Bumi Media.

Fitriyah, A. (2021). Kajian Etnomatematika terhadap Tradisi Weh-wehan di Kecamatan Kaliwungu Kendal. Jurnal Pendidikan Matematika Raflesia, 06(01).

Herdiansyah, Haris. (2012). Metodologi Penelitian Kualitatif untuk IImu-IImu Sosial. Jakarta: Salemba Humanika. 
Malikhah, Nurul Laili. (2019). Nilai-Nilai Dakwah dalam Tradisi Ketuwinan di Kecamatan Kaliwungu, Kabupaten Kendal. Semarang: eprintswalisongo.ac.id

Maryati, Kun dan Juju Suryawati. (2007). Sosiologi Jilid 2. Jakarta: Erlangga.

Muzzakir. (2018). Dukun dan Bidan dalam Perspektif Sosiologi. Makassar: CV Sah Media.

Rukin. (2019). Metode Penelitian Kualitatif. Sulawesi Selatan: Yayasan Ahmar Cendekia Indonesia.

Saleh, Akh. Muwafik. (2020). Hari-Hari Mencari Cinta. Yogyakarta: Gema Insani.

Sari, Pambayun Mustika Rahayu dan Agustinus Sugeng Priyanto. (2019). Silaturahim sebagai bentuk Utama dalam Kepedulian Sosial pada Tradisi Weh-Wehan di Kaliwungu, "Indonesian Journal of Conservation", Vol. 8, No. 1.

Simanjutak, Bungaran Antonius. (2016). "Tradisi, Agama, dan Akseptasi Modernisasi pada Masyarakat Pedesaan Jawa". Jakarta: Yayasan Pustaka Obor Indonesia.

Sofi, Rohmad. (2018). Perancangan Buku Ilustrasi Cerita Bergambar Makanan Tradisional dalam Tradisi Weh-Wehan di Kaliwungu, Kendal, UPT Perpustakaan ISI Yogyakarta: Jurnal Tugas Akhir.

Sutardi, Tedi. (2007). “Antropologi: Mengungkapkan Keragaman Budaya untuk Kelas XI Sekolah Menengah Atas/Madrasah Aliyah Program Bahasa". Bandung: PT Setia Purna Inves.

Tim Deputi Bidang Pelestarian dan Pengembangan Kebudayan. (2004). Kebijakan Pelestarian dan Pengembangan Kebudayan. Jakarta: Direktoral Jenderal Kebudayaan.

Wahidi, R. (2015). Budaya dan Agama sebagai Identitas Islam Nusantara; Kajian atas Tradisi Marhaba'an/ Maulid Nabi di Tanah Sunda. Jurnal Madania, 5(2), 200-218.

Wawancara dengan Apriliya, selaku masyarakat di Kaliwungu, Kendal, pada hari Minggu, 15 November 2020, pukul 17.58 WIB.

Wawancara dengan Dr. Mudjahirin Thohir, MA, selaku tokoh sejarah di Kaliwungu, Kendal, pada Selasa, 24 November 2020, pukul 19.15 WIB.

Wawancara dengan Nisrina Nur, selaku tokoh pelajar di Kaliwungu, Kendal, pada Kamis, 19 November 2020, pukul 21.04 WIB.

Yunus, M. (2020). Tradisi Perayaan Kenduri Maulid Nabi Di Aceh Besar. ADABIYA, 22(2), 32-48. 